\title{
A crop pest species of Cyclocephala Dejean (Coleoptera: Melolonthidae: Dynastinae) misidentified for over twenty years in Southern Brazil
}

\author{
Mariana Alejandra Cherman $1,3, \star$ (D), Paschoal Coelho Grossi² (iD) \\ 1. Universidade Federal do Paraná - Centro de Ciências Biológicas - Departamento de Zoologia - Curitiba (PR), Brazil. \\ 2. Universidade Federal Rural de Pernambuco - Departamento de Agronomia - Área de Fitossanidade - Recife (PE), Brazil. \\ 3. Universidade Federal de Mato Grosso - Instituto de Biociências - Departamento de Biologia e Zoologia - Cuiabá (MT), Brazil.
}

\begin{abstract}
A common white grub species associated with a wide range of crops in Southern Brazil has been named as Cyclocephala flavipennis Arrow for over twenty years. This work aimed to revise the identity of this species based on the study of primary types, identified material collected in previous works and descriptions on literature. The confirmed name for this white grub from Southern Brazilian crops was fixed to $C$. signaticollis Burmeister, an important pest of several no-tilling crops in Argentina, Uruguay and also in Australia, where it was introduced and is widely established. Taxonomical remarks on adults and larvae are included, in conjunction with depicted images of diagnostic characters. The geographical distribution of $C$. flavipennis from Southern South America is disregarded. New strategies of pest management for $C$. signaticollis should be assessed in Southern Brazil taking into account all the background of knowledge on this species from the neighboring countries.
\end{abstract}

Key words: Cyclocephala flavipennis Arrow, Cyclocephala signaticollis Burmeister, cockchafers, pest management, Scarabaeoidea, white grubs.
Received:

Feb. 25, 2020

Accepted:

Jun. 17, 2020

Section Editor:

Luís Garrigós Leite

${ }^{\star}$ Corresponding author: marianabioar@gmail.com

White grubs [Coleoptera: Melolonthidae sensu Cherman and Moron (2014)] are soil-dwelling beetle larvae that feed on the roots and seeds of various plants (Alvarado 1980). By early 1990s, with the advent of the no-tilling system, a Cyclocephala Dejean white grub species was first-time recorded by Gassen (1993) in Southern Brazilian crops, which was identified as C. flavipennis Arrow. This author mentioned the association of this species with maize (Zea mays L., Poaceae), barley (Hordeum vulgare L., Poaceae) and wheat (Triticum aestivum L., Poaceae) in great numbers, but also occurring in soybean (Glycine max (L.) Merr., Fabaceae), pastures and fields with abundant mulch covering the soil, common in no-tilling systems (Bolliger et al. 2006). Since Gassen (1993), all the subsequent works used this identification for referring to the same species. Those works included descriptions of life cycle, morphology, behavior, host plants and population parameters (Cargnelutti Filho et al. 2011; Cherman et al. 2013; 2014 a; b; Diez-Rodríguez et al. 2015; Duchini et al. 2017; Valmorbida et al. 2018 a; b).

This species, named "coró-pequeno", was long term considered harmless among the white grub complex (Cargnelutti Filho et al. 2011; Cherman et al. 2013; 2014 a; b; Valmorbida et al. 2018 a; b). Gassen (1993) reported that C. flavipennis, even when present in numbers exceeding 100 larvae $\mathrm{m}^{-2}$ did not cause damage to crops as long as sufficient soil cover for them to feed on was present, which characterizes the no-tilling systems. Despite that, recent field works from the Brazilian states of Santa Catarina and Rio Grande do Sul reported damages on roots assigned to larvae of C. flavipennis in fields of Urochloa decumbens Stapf 'Basilisk' (Poaceae) and blueberry, Vaccinium ashei Reade (Ericaceae), respectively (Diez-Rodríguez et al. 2015; Duchini et al. 2017).

Cyclocephala flavipennis is native to Ecuador (Arrow 1914), Brazil and Bolivia (Endrödi 1985); however, the only extant biological reports of C. flavipennis are from Southern Brazil. Another species, Cyclocephala signaticollis Burmeister, is one of the most common among the white grub assemblages from Argentina and Uruguay, and is also present in other South 
American countries such as Venezuela, Colombia, French Guyana, Brazil and Bolivia (Moore et al. 2018 a). Though, records of C. signaticollis as a pest of several garden and field crops, potato (Solanum tuberosum L.; Solanaceae) tubers, and improved pastures are restricted to Argentina, Uruguay, and also in Australia, where this species was introduced and is well established (Allsopp and Hutchinson 2019; Alvarado 1980; Bonivardo et al. 2015; Carne 1956; Castelo and Corley 2004; Dechambre 2005; Monteith 2017; Moore et al. 2018 a; Morelli 1991).

After comparing the available descriptions of larvae and adults of C. signaticollis with the collected Brazilian material of the so-far-known C. flavipennis, similarities between them were outstanding. As the taxonomic identification is the first step to establish a correct pest management, this fact encouraged a thorough revision of the available material and literature of $C$. flavipennis associated with Brazilian crops. Hence, the aim of the present report is to solve the real identity of Brazilian populations of what is called C. flavipennis, and to update the distribution of both species C. flavipennis and C. signaticollis in case of new records.

During 2018 and 2019, pinned adults of C. flavipennis and C. signaticollis were examined from the following institutions: the British Natural History Museum (BMNH), London; Universidade Federal de Mato Grosso, Setor de Entomologia da Coleção Zoológica (CEMT), Cuiabá; Coleção Entomológica da Universidade Federal Rural de Pernambuco (CERPE), Recife; Coleção do Departamento de Zoologia da Universidade de Brasília (DZUB), Brasília; Coleção Entomológica Pe. J. S. Moure (DZUP), Curitiba; Everardo \& Paschoal Grossi Collection (EPGC), Nova Friburgo; Muséum National d'Histoire Naturelle (MNHN), Paris; and Museum für Naturkunde (ZMHB), Berlin.

Adult specimens were identified by the comparison with the original descriptions of each species (Arrow 1914; Burmeister 1847 ) and the key to Dynastinae of Endrödi (1985). Primary types (syntypes) of C. flavipennis were found and examined at BMNH and ZMHB, as well as illustrations of Cyclocephala signaticollis female lectotype, housed at MNHN, Paris (Dechambre 1991). Nonetheless, the information of C. signaticollis comprised in the adult redescriptions (Carne 1956; 1957; Endrödi 1966; Morelli 1991), and that of larvae (Alvarado 1980; Carne 1956; Morelli 1991; Moore et al. 2018 b) are the necessary for identification purposes. Adults and larvae of C. flavipennis already collected in crops of Southern Brazil (Cherman et al. 2013; 2014 a; Duchini et al. 2017; Valmorbida et al. 2018 b), which are housed at the entomological collection of the Laboratório de Manejo Integrado de Pragas, Universidade Federal de Santa Maria, Santa Maria, Brazil, and at DZUP, were examined and compared with the lectotype and redescriptions of C. signaticollis. Observations were made with a WILD M5 stereomicroscope. The measurements were obtained using AxioVision SE64 V 4.8.3.0 for Windows. Male genitalia were dissected, studied and mounted beneath the specimen. The photographs were taken with a Leica DFC 500 digital camera, using Auto-Montage Pro (Syncroscopy) software and a Leica MZ16 stereomicroscope.

More than 100 adult specimens of C. signaticollis were examined with the following record data: Ecuador: Napo (2 specimens EPGC); Brazil: Paraná: Curitiba, Ponta Grossa, Castro, Palmas, Tibagi, Diamante do Norte, Guaratuba, Tijucas do Sul, Mananciais da Serra, Tamarana (50 specimens, CERPE and EPGC); Santa Catarina: Baixo Jordão, São Bento do Sul, Urubici, Bom Jardim da Serra, (30 specimens, EPGC, CERPE), Nova Teutônia (2 specimens, DZUP); Rio Grande do Sul: Porto Alegre, Bagé, São Francisco de Paula, Viamão, Eldorado do Sul (10 specimens CERPE, EPGC), Tupanciretã, Herval (2 specimens, DZUP). Argentina: Buenos Aires, Chascomús (2 specimens EPGC).

Based on both species' descriptions on literature, C. flavipennis primary types (Fig. 1a-d), and larvae collected, the authors of this work confirm that all the material already identified as C. flavipennis from Southern Brazil correspond indeed to C. signaticollis. Cyclocephala signaticollis (Fig. 1e-g) is distinguished from C. flavipennis (hereinafter within brackets) mainly by being smaller in size, $12-15 \mathrm{~mm}$ length [16-18 $\mathrm{mm}$ ]; light brown to brownish beige in color; pronotum somewhat darker than elytra, bearing dark brown markings more or less distinctive and bilaterally symmetrical [pronotum uniform red (Fig. 1a)] (Arrow 1914; Carne 1956; 1957). Contrary to Australian populations (Carne 1956), these pronotal markings are not extended along the elytral disc (Fig.le) in South American specimens. The shape of the parameres in both species is quite different (Fig. 1c-d, f-g). Regarding the larvae, according to Böving (1936), the term palidia is referred to the group of thick erect setae (pali) placed at the venter of last abdominal segment (raster) usually enclosing an area called septula. These setae could be disposed in singled or paired rows matching with the body axis or transverse, straight or convex; in this case they could be so convergent that they seem to form a circle. The setae on the raster of $C$. signaticollis match with the description of pali, following all previous descriptions (Alvarado 1980; Carne 1956; Morelli 1991), and are circle-like disposed, with one palus out of the common line among them. Moore et al. (2018 b) mentioned that larvae of C. signaticollis have absent palidia. The definition 


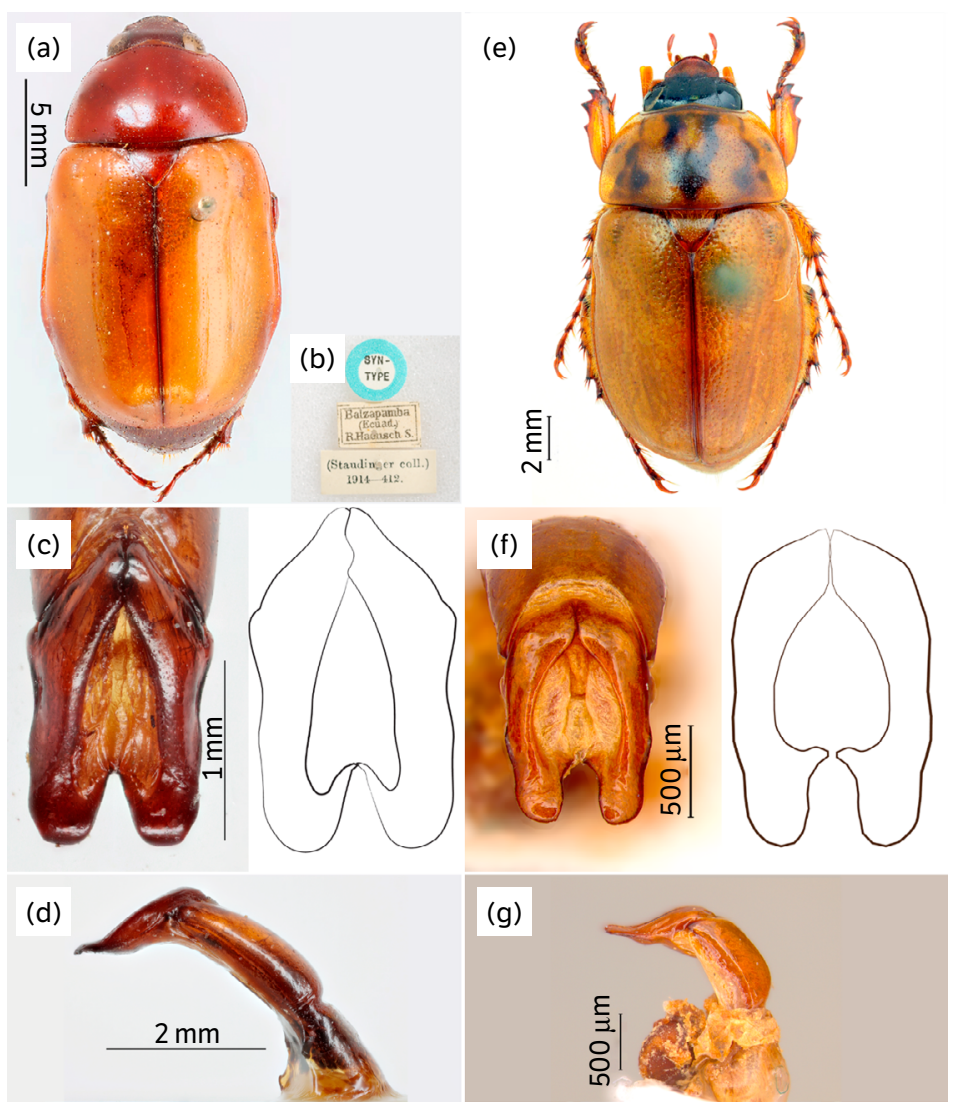

Figure 1. Cyclocephala flavipennis Arrow: (a) habitus; (b) syntype labels (BMNH); parameres in (c) dorsal, picture and scheme, and (d) lateral view. Cyclocephala signaticollis Burmeister: (e) habitus; parameres in (f) dorsal, picture and scheme, and (g) lateral view.

of Böving (1936) seems to be somewhat ambiguous because it leads to understand that if setae are not forming rows it is not a palidia. Currently, the diversity of melolontid larvae is thoroughly well known, and there is a vast number of different shapes that those setae can adopt. Hence, contrary to Moore et al. (2018 b), the authors of this work consider that this character is present in C. signaticollis. Immature stages, as well as biological data of $C$. flavipennis remain unknown.

In terms of geographical distribution, C. signaticollis remains with its records updated (Moore et al. 2018 a) plus a new record from Ecuador (Napo). As we were not able to find non-type material of $C$. flavipennis among the collections accessed, this species preserves the records cited until Endrödi (1985), which are Ecuador, Bolivia and the state of Rio de Janeiro (Brazil). All Southern Brazilian records are disregarded for C. flavipennis.

\section{ACKNOWLEDGMENTS}

The authors thank to the collection curators for the loan material, especially to Bernd Jäger (ZMHB), Rafael Sobral, and Maxwell Barclay (BMNH) for the pictures of primary types. They also thank the anonymous reviewers for critically evaluating the manuscript and providing their valuable suggestions.

\section{FUNDERS}

Conselho Nacional de Desenvolvimento Científico e Tecnológico

[http://doi.org/10.13039/501100003593]

Grants: \#151425/2019-1, \#449366/2014-6, \#424048/2018-3, and \#309786/2019-3. 
Deutscher Akademischer Austauschdienst

[http://doi.org/10.13039/501100001655]

Grant \# 91703090

Universidade Federal do Paraná

[http://doi.org/10.13039/501100008223]

Grant \# 1972

\section{AUTHOR'S CONTRIBUTION}

Conceptualization, Cherman M. A. and Grossi P. C.; Methodology, Cherman M. A. and Grossi P. C.; Investigation, Cherman M. A. and Grossi P. C.; Writing - Original Draft, Cherman M. A. and Grossi P. C.; Writing - Review and Editing, Cherman M. A. and Grossi P. C.; Funding Acquisition, Cherman M. A. and Grossi P. C.; Resources, Cherman M. A. and Grossi P. C.; Supervision, Cherman M. A. and Grossi P. C.

\section{REFERENCES}

Allsopp, P. G. and Hutchinson, P. (2019). Extralimital Dynastinae (Coleoptera: Scarabaeidae) in Australia. Journal of Insect Biodiversity, 12, 48-77. https://doi.org/10.12976/jib/2019.12.2.2

Alvarado, L. J. (1980). Sistemática y bionomia de coleopteros que en estados inmaduros viven en el suelo [Systematics and bionomics of coleoptera in immature states that live in the soil (en)]. (Thesis). Universidad Nacional de La Plata, La Plata.

Arrow, G. J. (1914). Some further notes on Lamellicorn beetles of the subfamily Dynastinæ. Annals and Magazine of Natural History, 14 , 360. https://doi.org/10.1080/00222931408693584

Bolliger, A., Magid, J., Amado, J. C. T., Skóra Neto, F., Ribeiro, M. F. S., Calegari, A., Ralisch, R. and Neergaard, A. (2006). Taking stock of the Brazilian "zero till revolution": A review of landmark research and farmers' practice. Advances in Agronomy, 91, 47-110. https://doi. org/10.1016/S0065-2113(06)91002-5

Bonivardo, S. L., Martínez, A. N., Mana, G. P. and Suarez, A. (2015). Relevamiento de escarabeidos (insecta, coleoptera) en pastizal natural, pasto llorón y maíz, en el este de la provincia de San Luis (Argentina) [Scarabaeidae survey of natural pastures, weeping lovegrass and corn in eastern province of San Luis (Argentina) (en)]. FAVE Sección Ciencias Agrarias, 14, 31-38. Spanish. https://doi. org/10.14409/fa.v14i2.5718

Böving, A. G. (1936). Description of the larva of Plectris aliena Chapin and explanation of new terms applied to the epipharynx and raster. Proceedings of the Entomological Society of Washington, 38, 169-185.

Burmeister, H. (1847). Handbuch der Entomologie: Besondere Entomologie, Fortsetzung: Coleoptera Lamellicornia Xylophila et Pectinicornia. Berlin: Reimer.

Cargnelutti Filho, A., Cherman, M. A., Guedes, J. V. C., Prá, E. D., Schallemberger, D. G. and Stürmer, G. R. (2011). Dimensionamento de amostra na estimação da população de corós em áreas de campo nativo e de cultivo no Estado do Rio Grande do Sul. Ciência Rural, 41, 1300-1306. https://doi.org/10.1590/S0103-84782011005000103

Carne, P. B. (1956). Cyclocephala signaticollis Burmeister, an introduced pasture scarab (Coleoptera). Proceedings of the Linnean Society of New South Wales, 81, 217-221. [Accessed Jul.72020]. Available at: https://www.biodiversitylibrary.org/item/108607\#page/250/mode/2up Carne, P. B. (1957). A systematic revision of the Australian dynastinae: (Coleoptera: Scarabaeidae). Australia: CSIRO Division of Entomology. 
Castelo, M. K. and Corley, J. C. (2004). Evaluación de la capacidad reguladora del moscardón cazador de abejas Mallophora ruficauda (Diptera: Asilidae) sobre los gusanos blancos del suelo (Coleoptera: Scarabaeidae) [Evaluation of the regulatory potential of robber fly Mallophora ruficauda (Diptera: Asilidae) on soil white grubs (en)]. Revista de Investigaciones Agropecuarias, 33, 61-80. Spanish.

Cherman, M. A., Guedes, J. V. C., Morón, M. Á., Prá, E. D. and Bigolin, M. (2013). White grubs (Coleoptera, Melolonthidae) in the “Planalto Region”, Rio Grande do Sul state, Brazil: Key for identification, species richness and distribution. Revista Brasileira de Entomologia, 57, 271-278. https://doi.org/10.1590/S0085-56262013000300005

Cherman, M. A. and Moron, M. Á. (2014). Validación de la familia Melolonthidae Leach, 1819 (Coleoptera: Scarabaeoidea). Acta Zoológica Mexicana (n.s.), 30, 201-220. https://doi.org/10.21829/azm.2014.301139

Cherman, M. A., Morón, M. Á., Prá, E. D., Valmorbida, I. and Guedes, J. V. C. (2014 a). Ecological characterization of white grubs (Coleoptera: Melolonthidae) community in cultivated and noncultivated fields. Neotropical Entomology, 43, 282-288. https://doi. org/10.1007/s13744-014-0214-0

Cherman, M. A., Morón, M. Á., Salvadori, J. R., Prá, E. D. and Guedes, J. V. C. (2014 b). Análise populacional de corós-praga e de outras espécies no planalto do Rio Grande do Sul. Ciência Rural, 44, 2095-2102. https://doi.org/10.1590/0103-8478cr20131443

Dechambre, R.-P. (1991). Désignation de lectotypes de Cyclocephala décrits par Burmeister [Coleoptera, Dynastidae] [Lectotypes designation of Cyclocephala described by Burmeister (Coleoptera dynastidae) (en)]. Revue française d'entomologie, 13, 123-124. French.

Dechambre, R.-P. (2005). Dynastidae australiens et océaniens. In Les Coleopteres du Monde [The Beetles of the World (en)]. Canterbury: Hillside Books. French.

Diez-Rodríguez, G. I., Hübner, L. K., Antunes, L. E. C., Guedes, J. V. C. and Nava, D. E. (2015). Registro de Cyclocephala flavipennis Arrow, 1914 (Coleoptera:Melolonthidae) danificando plantas de mirtileiro no Brasil. Ciência Rural, 45,189-191. https://doi.org/10.1590/0103-8478cr20140412

Duchini, P. G., Echeverria, J. R., Américo, L. F., Guzatti, G. C., Cherman, M. A. and Sbrissia, A. F. (2017). White grubs (Cyclocephala flavipennis) damaging perennial winter pastures in the South Region of Brazil. Ciência Rural, 47, e20160662. https://doi.org/10.1590/0103-8478cr20160662

Endrödi, S. (1966). Monographie der Dynastinae. Teil I. Zoologische Abhandlungen (Dresden), 33, 1-460.

Endrödi, S. (1985). The Dynastinae of the World. Netherlands: Springer.

Gassen, D. N. (1993). Características de disposição espacial de larvas de Diloboderus abderus, de Phytalus sanctipauli e de Cyclocephala flavipennis, em soja [Documento 9]. In EMBRAPA. Centro Nacional de Pesquisa de Trigo. Soja: resultados de pesquisa 1992-1993 (p. 175181). Passo Fundo: Embrapa Trigo. [Accessed Feb.12020]. Available at: https://ainfo.cnptia.embrapa.br/digital/bitstream/item/133624/1/ ID11102-1992-1993sojaresultados-p175-181.pdf

Monteith, G. (2017). The Argentinian scarab: the new kid on the block. News Bulletin, Entomological Society of Queensland, $44,200$.

Moore, M. R., Cave, R. D. and Branham, M. A. (2018 a). Annotated catalog and bibliography of the cyclocephaline scarab beetles (Coleoptera, Scarabaeidae, Dynastinae, Cyclocephalini). ZooKeys, 745, 101-378. https://doi.org/10.3897/zookeys.745.23685

Moore, M. R., Cave, R. D. and Branham, M. A. (2018 b). Synopsis of the cyclocephaline scarab beetles (Coleoptera, Scarabaeidae, Dynastinae). ZooKeys, 745, 1-99. https://doi.org/10.3897/zookeys.745.23683

Morelli, E. (1991). Descripción de la larva y de la pupa de Cyclocephala signaticollis Burmeister, 1847 (Coleoptera: Scarabaeidae: Dynastinae) y observaciones sobre su biología [Description of the larva and pupa of Cyclocephala signaticollis Burmeister, 1847 (Coleoptera: Scarabaeidae: Dynastinae) and observations about its biology (en)]. Elytron, 5, 189-195. Spanish.

Valmorbida, I., Cherman, M. A., Jahn, D. S. and Guedes, J. V. C. (2018 a). Abundance and diversity in the Melolonthidae community in cultivated and natural grassland areas of the Brazilian pampa. Environmental Entomology, 47,1064-1071. https://doi.org/10.1093/ee/nvy109

Valmorbida, I., Cherman, M. A., Perini, C. R., Cavallin, L. A. and Guedes, J. V. C. (2018 b). Population analysis of white grubs (Coleoptera: Melolonthidae) throughout the Brazilian Pampa biome. Revista Brasileira deEntomologia, 62, 275-282. https://doi.org/10.1016/j.rbe.2018.08.002 